\title{
The environmental cost of protein food choices
}

\author{
Joan Sabaté ${ }^{1, *}$, Kitti Sranacharoenpong ${ }^{1}$, Helen Harwatt ${ }^{1}$, Michelle Wien $^{2}$ and \\ Samuel Soret ${ }^{3}$ \\ 'Department of Nutrition, Loma Linda University, Nichol Hall 1 102, Loma Linda, CA 92350, USA: ${ }^{2}$ Human Nutrition \\ and Food Science Department, School of Agriculture, California State Polytechnic University, Pomona, CA, USA: \\ ${ }^{3}$ Department of Occupational and Environmental Health, Loma Linda University, Loma Linda, CA, USA
}

Submitted 3 January 2014: Final revision received 20 June 2014: Accepted 20 September 2014: First published online 6 November 2014

\begin{abstract}
Objective: To investigate the resource efficiency and environmental impacts of producing one kilogram of edible protein from two plant- and three animalprotein sources.

Design: Primary source data were collected and applied to commodity production statistics to calculate the indices required to compare the environmental impact of producing $1 \mathrm{~kg}$ of edible protein from kidney beans, almonds, eggs, chicken and beef. Inputs included land and water for raising animals and growing animal feed, total fuel, and total fertilizer and pesticide for growing the plant commodities and animal feed. Animal waste generated was computed for the animal commodities. Setting: Desk-based study at the Department of Nutrition and Department of Occupational and Environmental Health, Loma Linda University.

Subjects: None.

Results: To produce $1 \mathrm{~kg}$ of protein from kidney beans required approximately eighteen times less land, ten times less water, nine times less fuel, twelve times less fertilizer and ten times less pesticide in comparison to producing $1 \mathrm{~kg}$ of protein from beef. Compared with producing $1 \mathrm{~kg}$ of protein from chicken and eggs, beef generated five to six times more waste (manure) to produce $1 \mathrm{~kg}$ of protein. Conclusions: The substitution of beef with beans in meal patterns will significantly reduce the environmental footprint worldwide and should also be encouraged to reduce the prevalence of non-communicable chronic diseases. Societies must work together to change the perception that red meat (e.g. beef) is the mainstay of an affluent and healthy diet.
\end{abstract}

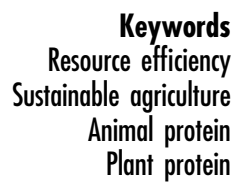

The agricultural sector serves many useful functions, including food provision, and uses a substantial amount of natural resources such as water, energy and land. Globally, agriculture accounts for $70 \%$ of water withdrawals ${ }^{(1)}$ and is within the highest energy-use category ${ }^{(2)}$. Approximately $2 \cdot 3$ million tonnes ( 5 billion pounds) of pesticides are applied globally every year ${ }^{(3)}$. Worldwide fertilizer use was about 180 million tonnes in 2012 and is forecast to increase ${ }^{(4)}$. More than one-third of the global ice-free land surface is used for food production ${ }^{(5)}$. With a forecasted growth in population of about 2 billion people by $2050^{(6)}$, the resources required for food production are set to increase considerably.

Numerous critical environmental issues are intensified by agricultural practices. In relation to water use, these include surface and groundwater pollution, over-drafting of aquifers and salinization of soils ${ }^{(7,8)}$. The use of fossil fuels contributes to air pollution, soil and water contamination and greenhouse gas emissions. Pesticides persist in the environment and result in surface and groundwater contamination, damage to non-targeted species and increased resistance in pests ${ }^{(8,9)}$. From the $\mathrm{N}$ applied in fertilizers, it is estimated that less than half is absorbed, with the remainder entering the environment and causing many problems such as surface and groundwater contamination, oceanic 'dead zones', a decrease in plant species and a reduced production of biomass ${ }^{(8)}$.

Climate change and other constraints, including land availability and rising levels of urbanization and industrialization, will continue to threaten food production with increasing severity ${ }^{(8,10)}$. Considered together with the need to generate fewer overall environmental impacts ${ }^{(11)}$, a more efficient use of resources for food production is essential within the context of food and nutrition security. While technology plays an important role in terms of increasing efficiency and in mitigating the adverse environmental impacts, the required reductions also necessitate behavioural change, i.e. a shift towards less resource-intensive food choices $^{(12-14)}$. Hence, a change in food consumption 
patterns has been described as inevitable ${ }^{,(12,15)}$. Nutritional provision should also be considered in such a dietary shift. Dietary protein and $\mathrm{N}$ are intrinsically and uniquely linked, hence protein is regarded as an essential nutrient given that $\mathrm{N}$ is a vital component of DNA, RNA and protein ${ }^{(15)}$. While also accounting for nutritional needs, the present investigation was designed to explore the resource requirements and waste products for a range of popular foods relatively high in protein.

\section{Experimental methods}

The present research utilized agricultural production data from the state of California. A variety of resources were reviewed and data were collected and applied to commodity production statistics. From this, indices were calculated and used for comparing the environmental impact associated with producing $1 \mathrm{~kg}$ of edible protein from two popular and nutrient-dense plant-protein sources (kidney beans and almonds) and three commonly consumed animal sources of protein (beef, chicken and eggs). The inputs that were measured in the study included the following: land $\left(\mathrm{m}^{2}\right)$; water $\left(\mathrm{m}^{3}\right)$ for growing plants, raising animals and growing animal feed; total fuel used at farms (litres; gasoline and diesel) for agricultural machinery and vehicles used for sowing, reaping and harvesting commodities and for the transport of commodities and personnel; and total fertilizer ( $\mathrm{g}$; N, P and $\mathrm{K}$ ) and pesticide ( $\mathrm{g}$ ) for growing the plant commodities and animal feed (maize, soyabean, alfalfa). Animal waste (kg; manure) was computed for the egg, chicken and beef commodities.

A prior California-based study ${ }^{(16)}$ contained algorithms, coefficients and calculations for the measured inputs. Additional information for computing the feeding rations for animals ${ }^{(17,18)}$, land usage ${ }^{(19,20)}$, total fuel requirements ${ }^{(21,22)}$, and fertilizer and pesticide use ${ }^{(21,23)}$ was reviewed. The information for animal waste generation was obtained from the Virginia Cooperative Extension, Virginia Tech ${ }^{(24)}$ and conversion factors to compute raw commodities to cooked foods (as commonly consumed) were obtained from the US Department of Agriculture Standard Reference $^{(25)}$ and $\mathrm{FAO}^{(26)}$ databases. Conversion factors were subsequently used to compute the production losses for the commodities from the farm to the retailer and from the raw to the cooked weight (moisture loss or gain).

Almonds and eggs from their raw weight at the farm to their edible weight on the table is the same, therefore a conversion factor is not indicated. The weight of dried kidney beans was converted to cooked kidney beans using a conversion factor of $2 \cdot 66^{(25)}$. In relation to chicken and beef production, weight losses at farms and processing plants were also taken into account. Cooking losses at the level of consumers' kitchens were also considered. On average by weight, $66 \%$ of chicken yield and $41 \%$ of beef yield are useable meat ${ }^{(26)}$ and the cooking losses for chicken and beef are $35 \%$ and $37 \%$, respectively ${ }^{(25)}$. Therefore, to combine weight and cooking losses for chicken and beef, $1 \mathrm{~kg}$ of raw meat was equal to 0.43 $(0.66 \times 0.65) \mathrm{kg}$ of cooked chicken and $0.26(0.41 \times 0.63) \mathrm{kg}$ of cooked beef. Flowcharts are included to provide examples of the production systems and inputs/outputs to produce edible plant- and animal-protein sources.

\section{Results}

Figures 1 and 2 show the flow of inputs and outputs to produce $1 \mathrm{~kg}$ of protein from kidney beans and $1 \mathrm{~kg}$ of protein from beef, respectively. Table 1 presents the required inputs and animal waste generated to produce $1 \mathrm{~kg}$ of edible protein for each of the five protein-rich commodities grown or raised in California. Land, water, fuel and fertilizer use ranged from 15.5 to $282.6 \mathrm{~m}^{2}$, from $10 \cdot 4$ to $109.0 \mathrm{~m}^{3}$, from 0.3 to 2.7 litres and from 160.5 to $1945.1 \mathrm{~g}$, respectively, with kidney beans having the lowest values and beef the highest values. Pesticide use ranged between 9 and $103 \mathrm{~g}$, with kidney beans having the lowest value and almonds having the highest value. Lastly, animal waste generated from the animal commodities ranged from $17 \cdot 1 \mathrm{~kg}$ to $105 \cdot 1 \mathrm{~kg}$, with eggs having the lowest value and beef the highest value.

Table 2 shows the relative environmental impact to produce $1 \mathrm{~kg}$ of edible protein for each of the five commodities grown or raised in California. Kidney beans were used as the referent value since they exhibited the lowest values for all measures. For animal waste generation, eggs were the referent value since they exhibited the lowest value for this measure. In relation to land, water, fuel, fertilizer and pesticide, in comparison to kidney beans, beef required eighteen, ten, nine, twelve and ten times more, respectively. Compared with chicken and eggs, beef generated five to six times more animal waste.

\section{Discussion}

Bean protein had the lowest requirements across the inputs measured. Similarly, previous analyses found soyabeans and other legumes to be less resource intensive in comparison to animal products ${ }^{(27-29)}$. Although almond protein required a relatively smaller amount of land and water compared with chicken and beef protein, the use of industrial agricultural practices in California increased its requirement for fuel, fertilizer and pesticides and closely approached or exceeded that of chicken and beef. The large quantity of resources required for farming almonds in California as measured in this comparative analysis limits their viability in terms of meeting the world's growing demand for protein. Among proteins of animal origin, egg production had the lowest requirement for fuel and produced the least amount of animal waste. The lower requirement for water, fertilizer and pesticide gives egg 


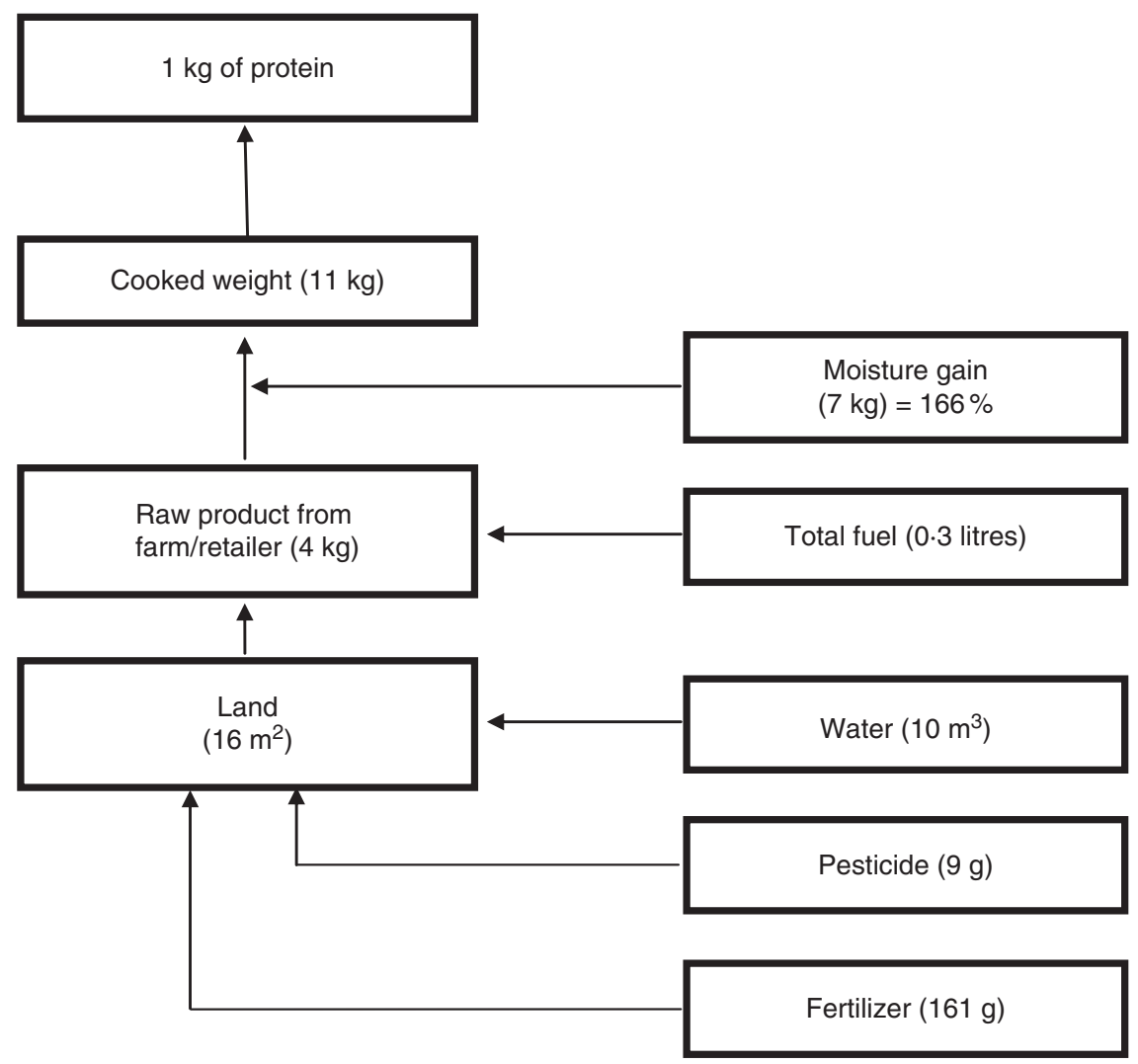

Fig. 1 A diagrammatic view of the inputs and outputs required to produce $1 \mathrm{~kg}$ of cooked edible protein from kidney beans

protein an advantage over protein from almonds, chicken and beef in these respects, which is consistent with a previous analysis $^{(27)}$. Among the protein sources studied, beef required the highest levels of inputs with the exception of pesticide, which is consistent with previous analyses ${ }^{(30)}$. If all of the resources required to produce $1 \mathrm{~kg}$ of protein from each food were combined, the demand for all inputs, except pesticide, would be dominated by beef.

The environmental footprint of food production varies widely between food groups. In general, the production of plant foods is more efficient and accounts for a smaller share of natural resource utilization and pollution impacts compared with the production of animal foods ${ }^{(8,31-34)}$. Inequality of inputs has always been recognized in the context of producing plant $v$. animal protein irrespective of the use of modern agricultural technological practices. 'Meat' production is environmentally unfriendly due to the need to produce feed for animals and the inherently inefficient conversion of plant protein to meat protein; thus, the direct human consumption of specific plant proteins requires only a fraction of the input of natural resources ${ }^{(35)}$. The livestock sector is responsible not only for a very large proportion of resource consumption, but also for environmental degradation including nutrient imbalances and climate change ${ }^{(14,30,36)}$. Wastes generated by intensified livestock production cause significant water, soil and air pollution and contamination of underground water with trace metals and zoonotic pathogens ${ }^{(8,37)}$.
Currently about $70 \%$ of agricultural land and $30 \%$ of the global land surface is used for livestock production. There is very limited scope to extend these areas without the reallocation of crop or forest land, both of which are undesirable ${ }^{(34)}$.

Dietary protein intake is essential for growth and for a vast array of biological processes in the human body. The safe total protein requirement for the maintenance of adequate protein nutriture for adults is $0.75 \mathrm{~g}$ protein $/ \mathrm{kg}$ body weight per $\mathrm{d}$, which equates to $\sim 10 \%$ of daily energy intake based on a person weighing $65 \mathrm{~kg}$ and consuming $8368 \mathrm{~kJ} / \mathrm{d}(2000 \mathrm{kcal} / \mathrm{d})^{(38)}$. Plant- and animal-based protein food sources have their distinctive nutritional values determined by their level of essential amino acids, which are utilized according to an individual's current physiological requirement and $\mathrm{N}$ balance. Further, individuals have a significant magnitude of metabolic flexibility in their day-to-day consumption of protein sources. The essential amino acids found in plant foods including legumes and nuts can satisfy physiological needs and exceed the requirement for adults in the context of an adequate total dietary protein supply equal to or above the aforementioned safe total protein intake ${ }^{(39)}$.

While the focus of the present study is protein, it is also insightful to consider the five commodities within a wider context. Using the cooked weights in Table 1 and deriving the energy density of each food ${ }^{(25)}$ reveals that the greatest provision is from almonds, followed by eggs, 


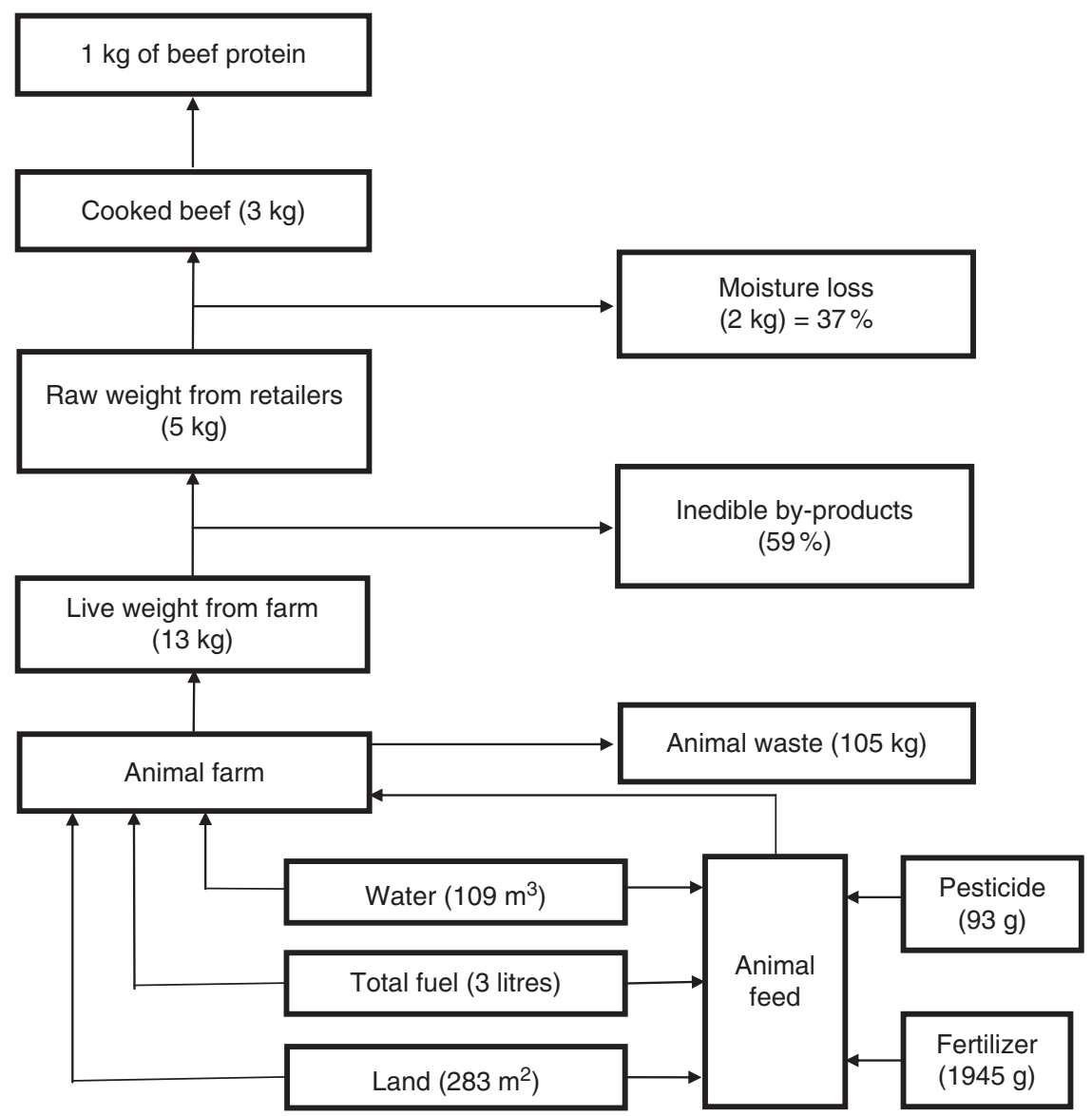

Fig. 2 A diagrammatic view of the inputs and outputs required to produce $1 \mathrm{~kg}$ of cooked edible protein from beef

Table 1 Inputs and animal waste generated to produce $1 \mathrm{~kg}$ of edible protein from each commodity grown or raised in California

\begin{tabular}{|c|c|c|c|c|c|}
\hline & Kidney beans & Almonds & Eggs & Chicken & Beef \\
\hline \multicolumn{6}{|l|}{ Food yields } \\
\hline Raw weight from farms (kg) & $4 \cdot 12$ & 4.75 & 8.00 & 9.72 & $13 \cdot 15$ \\
\hline Raw weight from retailers $(\mathrm{kg})$ & $4 \cdot 12$ & 4.75 & 8.00 & $6 \cdot 42$ & 5.40 \\
\hline Cooked weight (kg) & $10 \cdot 95$ & 4.75 & 8.00 & $4 \cdot 17$ & 3.40 \\
\hline Protein $(\mathrm{kg})$ & 1 & 1 & 1 & 1 & 1 \\
\hline \multicolumn{6}{|l|}{ Environmental factors } \\
\hline Land $\left(\mathrm{m}^{2}\right)$ & $15 \cdot 5$ & $21 \cdot 2$ & $37.6 \ddagger$ & $32 \cdot 2 \ddagger$ & $282 \cdot 6 \ddagger$ \\
\hline Water $\left(\mathrm{m}^{3}\right)$ & $10 \cdot 4$ & $23 \cdot 3$ & $11 \cdot 1 \S$ & $13 \cdot 5 \S$ & $109 \cdot 0 \S$ \\
\hline Fuel $^{*}$ (litres) & 0.3 & 0.6 & 0.6 & 0.7 & $2 \cdot 7$ \\
\hline Fertilizer† (g) & $160 \cdot 5$ & $426 \cdot 0$ & 263.6 & $320 \cdot 3$ & $1945 \cdot 1$ \\
\hline Pesticide (g) & 8.9 & $103 \cdot 6$ & $12 \cdot 7$ & $15 \cdot 5$ & 93.0 \\
\hline Animal waste $(\mathrm{kg})$ & - & - & $17 \cdot 1$ & 21.8 & $105 \cdot 1$ \\
\hline
\end{tabular}

${ }^{*}$ Total fuel includes gasoline and diesel used on the farm for agricultural and livestock production.

tTotal fertilizer includes $\mathrm{N}, \mathrm{P}$ and $\mathrm{K}$.

fLand used for raising animals and for growing animal feed.

$\S$ Water used for raising animals and for growing animal feed.

kidney beans, beef and chicken. This has implications for efficiency regarding the resource inputs required and the energy provision of each food. Chicken and beef are the least efficient in this respect. Such considerations are highly important within the context of food security and availability/scarcity. In terms of the macronutrient ratios by energy, when considered in isolation, kidney beans appear to offer the most balanced macronutrient ratio in relation to human needs, given the relatively high content of carbohydrate, lower levels of fat and ample levels of protein. More specifically, kidney beans have a ratio carbohydrate:protein:fat of $73: 24: 3$. This ratio varies only slightly between most beans, with the exception of soyabeans which have more protein and fat than kidney beans (carbohydrate:protein:fat of 23:34:43). Beans also provide high amounts of dietary fibre and are a rich source 
Table 2 Relative environmental impacts to produce $1 \mathrm{~kg}$ of edible protein from selected plant and animal sources grown or raised in California

\begin{tabular}{|c|c|c|c|c|c|}
\hline Environmentally relevant effect & Kidney beans* & Almonds & Eggs & Chicken & Beef \\
\hline Land & 1.00 & 1.37 & 2.43 & 2.08 & $18 \cdot 23$ \\
\hline Water & 1.00 & $2 \cdot 23$ & 1.07 & 1.29 & $10 \cdot 46$ \\
\hline Fuel & 1.00 & 1.90 & 1.86 & $2 \cdot 26$ & 8.59 \\
\hline Fertilizer & 1.00 & 2.65 & 1.64 & $2 \cdot 00$ & $12 \cdot 12$ \\
\hline Pesticide & 1.00 & 11.59 & 1.42 & 1.73 & $10 \cdot 40$ \\
\hline Animal waste† & - & - & 1.00 & 1.30 & $6 \cdot 20$ \\
\hline
\end{tabular}

${ }^{*} A$ referent value (1.00) is assigned to kidney beans to derive each input factor for the plant- and animal-based protein sources.

†A referent value (1.00) is assigned to eggs to derive the animal waste factor for the animal-based protein sources.

of vitamins and minerals, including Fe, as well as phytochemicals ${ }^{(25)}$. Hence, beans offer high-quality nutrition and are also the most resource-efficient to produce, in comparison to the other foods measured here.

Consuming plant foods such as beans and nuts is associated with many health benefits, including longevity ${ }^{(40,41)}$. Conversely, consuming animal products, particularly meat, is linked to poor health outcomes including CVD, obesity, diabetes and cancer ${ }^{(42-45)}$. The perception that animal products, particularly beef, are the mainstay of an affluent diet has the potential for tremendous public health and environmental backlash globally ${ }^{(15)}$. Therefore, there is a convergence of opinion among academics, politicians and non-governmental organizations based on a significant body of evidence to support the need to transition towards a plant-based diet for the health of human populations and to minimize the detrimental environmental impacts associated with food production ${ }^{(46-48)}$.

The present study was focused on the evaluation of five commodities grown or raised in the state of California, which has historically been the largest producer of agricultural food products in the USA and hosts a wide range of operations ${ }^{(49)}$. Additionally, California leads the nation in research and policy in the areas of environmental protection, natural resource conservation and sustainable agriculture $^{(50)}$. In light of the difficulty in obtaining reliable data on the quantities of antibiotics and growth hormones that are given to animals for disease prevention and enhanced yield, antibiotic and growth hormones were not included in the present analysis. Had this information been included, the differences in the environmental inputs between plant and animal protein would have been greater. Energy for storing the commodities from the time of purchase at the retailer to the time of meal preparation and plate waste at the consumer level were not included in the study. Lastly, protein formed the basis of this research and hence a detailed analysis including a nutritional profile to assess the overall quality of each food was not included.

\section{Conclusion}

In conclusion, producing protein from beans required the least amount of resource inputs while beef required the most, in addition to creating animal waste. Our findings concur with previous analyses that more environmentally friendly plant-protein food choices should be encouraged globally to reduce the intolerable environmental footprint associated with the production of animal-protein foods ${ }^{(8,30,34)}$. When the findings are considered within the broader context of public health nutrition, there are numerous advantages to be gained from reducing the consumption of animal products and adopting more plant-based food choices ${ }^{(41,42,45-49)}$. Societies will need to provide incentives to fuel the demand for such a dietary shift and must work together to change the perception that animal products, particularly beef, are the mainstay of an affluent and healthy diet.

\section{Acknowledgements}

Financial support: This research was supported by the Environmental Nutrition fund and the McLean fund of the Department of Nutrition, Loma Linda University. The funders had no role in the design, analysis or writing of this article. Conflict of interest: None. Authorship: J.S. obtained project funding, conceptualized the research design and was also responsible for data collection and analysis. K.S. was responsible for data collection, data analysis and conducting the research. H.H. made revisions and produced the final draft. M.W. produced the first draft of the manuscript. S.S. conceptualized the research design and was also responsible for data collection. All authors were involved in editing the manuscript. Ethics of buman subject participation: Ethical approval was not required.

\section{References}

1. Food and Agriculture Organization of the United Nations (2010) Water withdrawal by sector. AQUASTAT database. http://www.fao.org/nr/aquastat (accessed December 2013).

2. International Energy Agency (2012) 2012 Key World Energy Statistics. http://www.iea.org/publications/freepublications/ publication/kwes.pdf (accessed December 2013).

3. US Environmental Protection Agency (2006-2007) Pesticide Market Estimates: Usage. http://www.epa.gov/opp00001/ pestsales/07pestsales/usage2007.htm (accessed November 2013).

4. Food and Agriculture Organization of the United Nations (2011) Current world fertilizer trends and outlook to 2015. 
ftp://ftp.fao.org/ag/agp/docs/cwfto15.pdf (accessed November 2013).

5. Food and Agriculture Organization of the United Nations (2003) Compendium of Agricultural-Environmental Indicators 1989-2000. Rome: FAO, Statistics Analysis Service, Statistics Division.

6. United Nations (2004) World Population to 2300. New York: UN; available at http://www.un.org/esa/population/ publications/longrange2/WorldPop2300final.pdf

7. Tanji KK \& Enos CA (1994) Global water resources and agricultural use. In Management of Water Use in Agriculture, pp. 3-24 [KK Tanji and B Yaron, editors]. Berlin: Springer-Verlag.

8. Horrigan L, Lawrence R \& Walker P (2002) How sustainable agriculture can address the environmental and human health harms of industrial agriculture. Environ Health Perspect 5, 445-456.

9. Kiraly Z (1996) Sustainable agriculture and the use of pesticides. J Environ Sci Health B B31, 283-291.

10. Rockstrom J, Steffen W, Noone K et al. (2009) A safe operating space for humanity. Nature 24, 472-475.

11. Howden SM, Soussana JF, Tubiello FN et al. (2007) Adapting agriculture to climate change. Proc Natl Acad Sci USA 104, 19691-19696.

12. Garnett $\mathrm{T}$ (2011) Where are the best opportunities for reducing greenhouse gas emissions in the food system (including the food chain)? Food Policy 36, Suppl. 1, S23-S32.

13. Popp A, Lotze-Campen H \& Bodirsky B (2010) Food consumption, diet shifts and associated non- $\mathrm{CO}_{2}$ greenhouse gases from agricultural production. Global Environ Chang 20, 451-462.

14. Foley JA, Ramankutty N, Brauman KA et al. (2011) Solutions for a cultivated planet. Nature 478, 337-342.

15. Aiking H (2011) Future protein supply. Trends Food Sci Technol 22, 112-120.

16. Marlow H (2006) The Environmental Impact of Dietary Choice and Agriculture in California. Loma Linda, CA: Department of Occupational and Environmental Health, Loma Linda University.

17. Ernst R (1995) Poultry Fact Sheet No. 20: Chicken Meat Production in California. Davis, CA: University of California, Avian Sciences Department.

18. Prigge EC (2011) Rations for Growing Cattle. http://www. wvu.edu/ agexten/forglvst/rations.htm (accessed August 2011).

19. US Department of Agriculture (2008) Livestock Slaughter 2007 Summary. Washington, DC: USDA, National Agricultural Statistics Service.

20. Teaster S, Hammett L, Long W et al. (2009) Regional Land for Food. A Report of University of Virginia. Charlottesville, VA: University of Virginia.

21. Manitoba Agriculture, Food and Rural Initiatives, Policy Analysis Knowledge Centre (2007) Guidelines for Estimating Soybean Production Costs. Manitoba: Manitoba Agriculture, Food and Rural Initiatives, Policy Analysis Knowledge Centre.

22. American Public Transportation Association (2006) Public Transportation Fact Book, Table 4-16M. Washington, DC: APTA.

23. University of California, Davis (2000) Cost and Return Studies. Davis, CA: Agricultural and Resource Economics.

24. Ogejo J (2009) Selection and Location of Poultry and Livestock Manure Storage. Richmond, VA: Biological Systems Engineering, Virginia Cooperative Extension, Virginia Tech.

25. US Department of Agriculture, Agricultural Research Service (2011) USDA National Nutrient Database for Standard Reference, Release 24. Nutrient Data Laboratory Home Page. http://www.ars.usda.gov/ba/bhnrc/ndl (accessed September 2011).
26. Verheijen LAHM, Wiersema D, Hulshoff Pol LW et al. (1996) Livestock and the Environment - Finding a Balance. Management of Waste from Animal Product Processing. Coordinated by the FAO, USAID and World Bank. http:// www.fao.org/ag/againfo/programmes/en/lead/toolbox/Refer/ IACwaste.PDF

27. Carlsson-Kanyama A \& Gonzalez AD (2009) Potential contributions of food consumption patterns to climate change. Am J Clin Nutr 89, issue 5, 1704S-1709S.

28. Gonzalez AD, Frosetll B \& Carlsson-Kanyama A (2011) Protein efficiency per unit energy and per unit greenhouse gas emissions: potential contribution of diet choices to climate change mitigation. Food Policy 36, 562-570.

29. Reijnders L \& Soret S (2003) Quantification of the environmental impact of different dietary protein choices. Am J Clin Nutr 78, 3 Suppl, 664S-668S.

30. Goodland R \& Anhang J (2009) Livestock and climate change: what if the key actors in climate change are ... cows, pigs, and chickens. World Watch Inst 22, November/ December issue, 10-19.

31. Carlsson-Kanyama A, Ekstrom MP \& Shanahan H (2003) Food and lifecycle energy inputs: consequences of diet and ways to increase efficiency. Ecol Econ 44, 293-307.

32. Baroni L, Cenci L, Tettamanti M et al. (2007) Evaluating the environmental impact of various dietary patterns combined with different food production systems. Eur J Clin Nutr 61, 279-286.

33. Marlow HJ, Hayes WK, Soret S et al. (2009) Diet and the environment: does what you eat matter? Am J Clin Nutr $\mathbf{8 9}$, issue 5, 1699S-1703S.

34. Stehfest EBL, van Vuuren DP, den Elzen MGJ et al. (2009) Climate benefits of changing diet. Climate Change 95 , 83-102.

35. Aiking H, Helms M, Niemeijer D et al. (2006) The protein chains: pork vs. pea-based NFPs. In Sustainable Protein Production and Consumption: Pigs or Peas?, pp. 27-50 [H Aiking, J de Boer and J Vereijken, editors]. Dordrecht: Springer.

36. Eshel G \& Martin PA (2009) Geophysics and nutritional science: toward a novel, unified paradigm. Am J Clin Nutr 89, issue $5,1710 \mathrm{~S}-1716 \mathrm{~S}$.

37. Akhtar AZ, Greger M, Ferdowsian H et al. (2009) Health professionals' role in animal agriculture, climate change, and human health. Am J Prev Med 36, 182-187.

38. Food and Agriculture Organization of the United Nations/ World Health Organization/United Nations University (1985) Energy and Protein Requirements. Report of Joint FAO/WHO/UNU Expert Consultation. Geneva: WHO.

39. Young VR \& Pellett PL (1994) Plant proteins in relation to human protein and amino acid nutrition. Am J Clin Nutr 59 , 5 Suppl., 1203S-1212S.

40. Sabate J \& Ang Y (2009) Nuts and health outcomes: new epidemiologic evidence. Am J Clin Nutr 89, issue 5, 1643S-1648S.

41. Darmadi-Blackberry I, Wahlqvist ML, Kouris-Blazos A et al. (2004) Legumes: the most important dietary predictor of survival in older people of different ethnicities. Asia Pac J Clin Nutr 13, 217-220.

42. Richman EL, Stampfer MJ, Paciorek A et al. (2010) Intakes of meat, fish, poultry, and eggs and risk of prostate cancer progression. Am J Clin Nutr 91, 712-721.

43. Pan A, Sun Q, Bernstein AM et al. (2012) Red meat consumption and mortality: results from 2 prospective cohort studies. Arch Intern Med 172, 555-563.

44. Huang W, Han Y, Xu J et al. (2013) Red and processed meat intake and risk of esophageal adenocarcinoma: a metaanalysis of observational studies. Cancer Causes Control 24, 193-201.

45. Micha R, Wallace SK \& Mozaffarian D (2010) Red and processed meat consumption and risk of incident 
coronary heart disease, stroke, and diabetes mellitus: a systematic review and meta-analysis. Circulation 121, 2271-2283.

46. Food and Agriculture Organization of the United Nations (2009) The State of Food and Agriculture: Livestock in the Balance. Rome: FAO.

47. World Health Organization (2004) Global Strategy on Diet, Physical Activity and Health. Geneva: WHO.

48. Burlingame B \& Durnini S (editors) (2010) Sustainable Diets and Biodiversity. Directions and Solutions for Policy,
Research and Action. Proceedings of the International Scientific Symposium Biodiversity and Sustainable Diets United Against Hunger, 3-5 November 2010, Rome, FAO Headquarters. Rome: FAO.

49. Weick C (2001) Agribusiness technology in 2010: directions and challenges. Technical Society 23, 59-72.

50. Clark S, Klonssky K, Livingston P et al. (1999) Crop-yield and economic comparisons of organic, low-input and conventional farming systems in California's Sacramento Valley. Am J Altern Agric 14, 109-121. 